\title{
Improving the regulation of the derivatives market as an objective prerequisite for sustainable development of the global financial system
}

\author{
Oksana Novak $^{1 *}$, Oleksandr Melnychenko ${ }^{2,3}$, and Oksana Oliinyk ${ }^{4}$ \\ ${ }^{1}$ Zhytomyr Polytechnic State University, Department of Finance and Credit, 10005 Zhytomyr, \\ Ukraine \\ ${ }^{2}$ The London Academy of Science and Business, London, W1U 6TU, United Kingdom \\ ${ }^{3}$ Gdansk University of Technology, Department of Finance, 80-233 Gdansk, Poland \\ ${ }^{4}$ Zhytomyr Polytechnic State University, 10005 Zhytomyr, Ukraine
}

\begin{abstract}
The development of financial markets is characterized by the emergence of new financial instruments, in particular derivatives, the risk level analysis of which is complicated. Counterparties are not always fully aware of and do not adequately assess the potential risks of derivatives, which may lead to large financial losses and sometimes bankruptcies. The purpose of the study is to generalize approaches to regulating derivative markets and analyse the adequacy of regulatory influence to ensure sustainable development of the global financial system. The article analyses the approaches of scientists and regulators of the USA and the EU to the regulation of the derivatives market before and after the financial crisis of 2007-2008. Prior to the crisis, most scholars took a liberal approach to derivatives market regulation and recommended monitoring new instruments and not restricting their circulation in any way, emphasizing that effective counterparty risk management and their propensity for selfpreservation can prevent excessive risk-taking. The authors analyse the potential risks of derivatives and conclude that exchange-traded derivatives can cause similar processes of liquidity crisis, and, therefore, need additional regulatory tools to ensure the stability of the financial system
\end{abstract}

\section{Introduction}

In recent decades, the development of the global financial system has been characterized by high dynamics. The development of hardware and software accelerates the speed of capital turnover, expands the access of potential participants to financial markets, helps to increase the level of financial literacy of the population, which, in turn, affects the growth of capitalization of global financial markets. Financial services in the fierce competition are

\footnotetext{
${ }^{*}$ Corresponding author: novak_os@ukr.net
} 
replenished with new complex financial products that are not always fully understood by end customers. The obvious benefits of derivative financial instruments often mask the potential risks of catastrophic losses for commercial banks, other financial institutions, or nonfinancial corporations.

Prominent examples of financial fiasco with derivative financial instruments were the following: the bankruptcy in 1995 of the investment Barings Bank (with a 233-year history), due to the fact that the trader of the Singapore branch of the bank in a very short time lost $\$$ 1.3 billion on futures and options contracts on the Nikkei 225 Index [1]. The Fed's financial assistance to the investment bank Bear Stearns, which was one of the major players in the market for credit default swaps issued on "toxic" assets that burdened the balance sheets of other banks and the bankruptcy of the investment bank Merrill Lynch due to excessive CDO issues falling in price. Unprecedented in the history of the United States was the case of nationalization of life insurance company AIG, whose management before the collapse of the real estate market opened a long position in credit default swaps of 50 billion US dollars; the total amount of loans provided by the US government to AIG reached 223 billion US dollars [2]. The largest losses from transactions with derivatives are given in chronological sequence in Table 1.

Table 1. Examples of the biggest losses from derivatives trading $[2,3,4]$.

\begin{tabular}{|c|c|c|c|}
\hline Year & $\begin{array}{c}\text { Nominal } \\
\text { amount lost }\end{array}$ & Company & Source of Loss \\
\hline 1964 & USD $8 \mathrm{mn}$ & Citibank & Forwards \\
\hline 1987 & USD $0.80 \mathrm{bn}$ & Soros Fund & SP 500 Futures \\
\hline 1993 & DEM 2.63 bn & Metallgesellschaft & Oil Futures \\
\hline 1993 & JPY 166 bn & Showa Shell Sekiyu & FX Forwards \\
\hline 1994 & USD $1.7 \mathrm{bn}$ & Orange County & $\begin{array}{l}\text { Leveraged bond investments, } \\
\text { interest rate derivatives }\end{array}$ \\
\hline 1994 & JPY 153.6 bn & Kashima Oil & FX Forwards \\
\hline 1994 & USD 0.16 bn & Procter \& Gamble & Interest Rate Derivatives \\
\hline 1995 & GBP $827 \mathrm{mn}$ & Barings Bank & Nikkei Futures \\
\hline 1996 & JPY 285 bn & Sumitomo Corporation & Copper Futures \\
\hline 1998 & USD 4.6 bn & $\begin{array}{l}\text { Long Term Capital } \\
\text { Management }\end{array}$ & $\begin{array}{l}\text { Bond Arbitrage, interest rate } \\
\text { derivatives }\end{array}$ \\
\hline 1998 & CHF 0.63 bn & Union Bank of Switzerland & Equity Derivatives \\
\hline 2002 & USD $0.69 \mathrm{bn}$ & AIB/Allfirst & Foreign Exchange Options \\
\hline 2006 & USD 6.5 bn & Amaranth Advisors & Gas Futures \\
\hline 2008 & USD 9 bn & Morgan Stanley & Credit Default Swaps \\
\hline 2008 & $\begin{array}{l}\text { USD 6.12 } \\
\text { (EUR 4.9) bn }\end{array}$ & Société Générale & European Index Futures \\
\hline 2008 & USD 1.8 bn & Deutsche Bank & Derivatives \\
\hline 2008 & JPY 22.9 bn & Nanzan Gakuen & Equity Derivatives \\
\hline 2008 & $\begin{array}{l}\text { USD } 0.120 \\
\text { bn }\end{array}$ & Morgan Stanley & Credit-index options \\
\hline 2008 & $\begin{array}{l}\text { more than } \\
\text { USD } 150 \text { bn }\end{array}$ & AIG & Credit Default Swaps \\
\hline 2012 & USD 9 bn & JPMorgan Chase & Credit Default Swaps \\
\hline 2021 & USD 10 bn & $\begin{array}{l}\text { Archegos Capital } \\
\text { Management }\end{array}$ & Total return swaps \\
\hline
\end{tabular}


Table 1. shows examples of the most well-known cases of losses from transactions with derivative financial instruments, which, in practice, are much more; and all of them involve conscious or unconscious underestimation of the risk of derivatives. The need for regulating DFI markets is the subject of discussions for government regulators, as well as the scientific community.

\section{Literature Review}

Despite the fact that the derivatives market is relatively new, today, there are many thorough studies of the theoretical foundations of its operation. The essence and features of financial derivatives were considered in the works by John Hull, S.S.S. Kumar, S. Das and many others. Dzh. Sinki, S. Janakiramanan, Don M. Chance, R. devoted their works to the study of derivatives in the context of risk management. There are also works in which the focus is on OTC derivatives as those characterized by a higher level of risk, in particular, these issues were studied by: F.R. Edwards, D. Franzen, D. Murphy. The regulation of derivatives markets was considered in the works by L. Hentschel and C.W. Smith, M.S. Scholes, T. Frankel, F.A. Wolak, A. Alder, F. Laurens. However, despite the significant contribution of scientists to studying the nature of derivatives, opinions on their impact on the stability of the financial system and the need for their regulation differ.

\section{The Aim of the Study}

The aim of the study is to generalize approaches to the regulation of derivative markets and analyse the adequacy of regulatory influence to ensure sustainable development of the global financial system.

\section{Results}

In particular, referring to the bankruptcy of Barings, J. Sinkey Jr. argues that both buyers and sellers of derivatives should use mechanisms of adequate internal control. The researcher notes that "most derivative transactions are a "zero-sum game", so the 1994 and 1995 crises did not require government or regulatory intervention. Internal control and external market monitoring in such cases is better than regulatory intervention", - the author believes [5].

In 1994, researchers Hentschel Ludger and Clifford W. Smith in their work "Risk and Regulation in Derivative Markets" concluded that the risks of derivatives are exaggerated, and the history of derivatives regulation can be explained by the cautious reactions of benevolent regulators to emerging markets and unfamiliar tools. At the same time, the authors warned against political pressure to increase regulatory influence, as they saw this as a reduction in the efficiency of the derivatives market and the financial system as a whole [6].

M. S. Scholes was also a supporter of minimal regulatory intervention in derivatives markets, who saw the best alternative to regulatory influence in infrastructure development and the formation of sufficient contingent capital by dealers to support their business with DFI. In this study, the author argues that "there is no empirical evidence that supports the conjectures that OTC derivative contracts can lead to massive failures and create systemic risk" [7].

In a study by F.R. Edwards, the author argues that the "notion that the expansion of OTC derivatives markets has somehow increased the likelihood of a systemic crisis has no obvious factual basis". Paying attention to the painstaking work of rating agencies and the need for 
self-preservation, the researcher considers these factors to be sufficient incentives for dealers to properly manage risk and capital [8].

At the same time, even before the global financial crisis of 2008 , which was catalysed by (credit) derivatives, there were warnings about the potential danger of the latter from regulators and some of Wall Street's biggest investors, including Warren Buffett.

In Berkshire Hathaway's 2002 annual report, Warren Buffett wrote about derivatives: "We view them as time bombs, both for the parties that deal in them and the economic system... Derivatives contracts are of varying duration (running sometimes to 20 or more years) and their value is often tied to several variables... Unless derivatives contracts are collateralized or guaranteed, their ultimate value also depends on the creditworthiness of the counterparties to them. In the meantime, though, before a contract is settled, the counterparties record profits and losses - often huge in amount - in their current earnings statements without so much as a penny changing hands. The range of derivatives contracts is limited only by the imagination of man... Knowledge of how dangerous they are has already permeated the electricity and gas businesses, in which the eruption of major troubles caused the use of derivatives to diminish dramatically. Elsewhere, however, the derivatives business continues to expand unchecked. Central banks and governments have so far found no effective way to control, or even monitor, the risks posed by these contracts" [9].

The issues of regulating DFI markets, including over-the-counter, became especially relevant after the events of 2008, when financial markets were shaken by a wave of defaults, and the world's leading financial institutions such as Bear Stearns, Merrill Lynch, Lehman Brothers, AIG and others were on the verge of bankruptcy. However, the views of scholars, practitioners and regulators on the regulation of derivative markets are still conflicting.

Tamar Frankel, Professor of Law at Boston University, in his study "How Should the Financial Markets Be Regulated?" argues that "the financial markets should be regulated mostly by examinations, not by prosecution. And examinations should be far more intense when prices rise, not after a crash" [10].

The author emphasizes that "it makes more sense to devote most of the Securities and Exchange Commission's resources to on-going examinations. The examinations should focus on (1) large institutions (financial or industrial), whose failure by fraud might affect investors' trust in prices and lead to a crash; and (2) institutions whose share-prices have risen persistently signalling the "too good to be true" syndrome. The focus of the examinations should be on institutions whose failure may shake the system" [10].

Tamar Frankel suggests that inflating financial bubbles is inevitably accompanied by violations of the law, which leads to inflated prices. The author recommends an approach in which "examiners should learn about - not regulate - unregulated financial techniques, and acquire knowledge which they should share with colleagues. If regulators understand today's bubble mechanisms and identify attendant violations of the law, they could stem the trend towards empty prices before they rise and inevitably result in a painful crash" [10].

This approach has a certain logic; however, it should be noted that there may be some gaps in the legislation that allow activities in the field of financial markets, which leads to the formation of financial bubbles. Given that financial regulators do not have legislative powers, no matter how detailed they study the mechanisms of inflating financial bubbles, they will not be able to change the law, and therefore prevent these processes. Moreover, the lack of regulatory tools in the field of DFI markets, in fact, deprives financial regulators of any influence on the described phenomena.

Frank A. Wolak from Stanford University emphasizes that the most successful companies with the largest market capitalization are the American ones. The author notes that this affiliation is not accidental, because the capital market in the United States is not regulated, which creates conditions for the development of new financial instruments that allow more efficient management of financial resources of successful companies. The researcher 
emphasizes that the main purpose of regulating financial markets is to protect the rights of consumers of financial services - households.

"Consequently, there is scope for a regulatory process that ensures the household does not take excessive mortgage or retirement-savings risks. The Federal Deposit Insurance Corporation's (FDIC's) guarantee of a household's bank deposits against the failure of its bank is another example of consumer-protection regulation against the collateral damage of a bank that is poorly managed", the author notes [11].

In addition, as another example of consumer-protection regulation, the author mentions “The Consumer Financial Protection Bureau's Consumer Complaint Database, which allows consumers to submit complaints about their dealings with banks and financial firms over mortgages, credit cards, debt collection and other issues". However, the scientist also points out "the shortcoming of this database, which only covers complaints made to financial institutions with more than US $\$ 10$ billion in assets, so it misses the vast majority of depository institutions".

"With these consumer protections in place, the financial-sector regulatory process should limit its interventions into the day-to-day operational and risk-management activities of financial firms. These firms should be permitted to trade sophisticated financial instruments among themselves and with sophisticated market participants. Prohibitions on financial firms taking positions in physical commodities or financial derivatives based on physical commodity prices should also be eliminated. Although it is possible that some of these sophisticated players could incur large losses or even be forced to exit the industry", Frank A. Wolak summarizes [11].

As for regulators, even Basel Committee on Banking Supervision admitted that the assumptions that OTC derivatives market participants' risk management and capital discipline were sufficient to avoid a systemic crisis were incorrect [12].

So, following the onset of the credit crunch in 2007, the G20 group of countries agreed that the largely unregulated over-the-counter (OTC) derivatives market presented a major risk to the stability of the financial markets generally. This led to the implementation of Regulation (EU) 648/2012 on the European Market Infrastructure Regulation (EMIR) in the EU and the Dodd Frank Wall-Street Reform and Consumer Protection Act of 2010 (the Dodd-Frank Act) in the US [13].

The regulation of financial derivatives in the US is handled by both the Securities and Exchange Commission (SEC) and the Commodity Futures Trading Commission (CFTC). The parties to financial derivative contracts are regulated by the Financial Industry Regulatory Authority (FINRA). The National Futures Association (NFA) also has an important role to play in the oversight of these markets and their participants. The DoddFrank Act has provided for the regulation of derivative contracts which were effectively deregulated by the Commodity Futures Modernisation Act of 2000 [13].

Legislation governing the market for derivative financial instruments in the world's leading countries has some differences. However, both the EU and the USA focus on regulating OTC derivatives.

In the United States, the key provision of the regulation of financial derivatives introduced by the Dodd-Frank Act is the central clearing and reporting of over-the-counter (OTC) derivative transactions.

The OTC derivatives market will be subject to a requirement that all transactions are cleared through a central clearing house and reported to central repositories. The Dodd-Frank Act is intended to achieve two things in this regulation:

1. to remove the threat of a major counterparty failure from the financial system of the kind seen by the collapse of Lehman Brothers or AIG, and

2. to provide regulators with data as to the size and nature of a market which is globally measured in trillions of US dollars. 
The Dodd-Frank Act categorises regulated market participants as "swap dealers" and "major swap participants". Swap dealers and major swap participants will be required to comply with capital and margin business conduct requirements implemented by the SEC and CFTC [13].

In the European Union, the legislation governing financial derivatives markets is somewhat more complex, and its rules are somewhat stricter than in the USA.

The key current EU regulations affecting derivatives are:

1. The European Market Infrastructure Regulation (EU) 648/2012 (OJ L 201, 27.7.2012, p.1) (EU EMIR) as amended by EU EMIR REFIT (Regulation (EU) 2019/834 (OJ L 141/42)) and EU EMIR 2.2 (Regulation (EU) 2019/2099 (OJ L 322/1), Alternative Investment Fund Managers Directive 2011/61/EU (AIFMD)

2. Bank Recovery and Resolution Directive (2014/59/EU) (EU BRRD) and Directive (EU) 2019/879 (OJ L 150/296 (EU BRRD II) which amends it

3. The Capital Requirements Regulation (EU) 575/2013 (EU CRR) and Regulation (EU) 2019/876 (EU CRR II) which amends it, and the Capital Requirements Directive 2013/36/EU (EU CRD IV)

4. The Market Abuse Regulation (EU) 596/2014 (OJ L 173/1) (EU MAR)

5. The recast Markets in Financial Instruments Directive 2014/65/EU (EU MiFID II) and the Markets in Financial Instruments Regulation (EU) 600/2014 (EU MiFIR) (together, the EU MiFID II regime)

6. PRIIPs Regulation (EU) 1286/2014 (EU PRIIPs)

7. Short Selling Regulation (EU) 236/2012

8. Solvency II Directive 2014/17/EU (OJ L 60/34) (EU Solvency II)

9. UCITS IV Directive 2009/65/EC (EU UCITS IV) as amended by the UCITS V Directive 2014/91/EU (EU UCITS V) [14].

The last regulations adopted in the EU were MiFID II/MiFIR, which entered into force on 3 January 2018.

MiFID II and MiFIR will "ensure fairer, safer and more efficient markets and facilitate greater transparency for all participants". New reporting requirements and tests will increase the amount of information available, and reduce the use of dark pools and OTC trading. The rules governing high-frequency-trading will impose a strict set of organisational requirements on investment firms and trading venues, and the "provisions regulating the nondiscriminatory access to central counterparties (CCPs), trading venues and benchmarks are designed to increase competition" [15].

"The protection of investors is strengthened through the introduction of new requirements on product governance and independent investment advice, the extension of existing rules to structured deposits, and the improvement of requirements in several areas, including on the responsibility of management bodies, inducements, information and reporting to clients, cross-selling, remuneration of staff, and best execution" [15].

On 17 May 2021, the International Organisation of Securities Commissions (IOSCO) published a speech by Ashley Alder (CEO Hong Kong Securities and Futures Commission and IOSCO chair) entitled "A global perspective on derivatives regulation". In the report, among other things, the author noted:

- "There are no international standards for the amount and composition of the financial resources to fund central counterparty recovery and resolution. The FSB issued guidance last year to help authorities determine whether there are any gaps in the adequacy of financial resources and the treatment of equity. However, the outstanding question is whether the CCP rule books provide sufficient incentives for all stakeholders to facilitate an orderly resolution. The FSB, CPMI and FSB are working to tackle this issue.

- The BCBS-IOSCO margin requirements for non-centrally cleared derivatives are in the process of being implemented in stages, but with some delays. In the summer of 2019, full 
implementation was deferred by a year because of operational concerns and a further delay was announced a year later to cope with additional operational challenges posed by the COVID-19 pandemic. The final implementation phase is now scheduled for September 2022" [16].

Thus, even the regulations of the derivatives market, adopted in response to the crisis of 2007-2008, have not been fully implemented and are currently postponed until the autumn of 2022.

In addition, most regulations relate to the functioning of the central counterparty as a guarantor of the execution of agreements and the level of disclosure of derivative contracts. However, the sufficiency of these tools to ensure the stability of DFI markets has been questioned by scientists even before they were enshrined in regulations.

In particular, Hills, Rule, and Parkinson in their study, argued, that "a central counterparty does not of itself remove credit risk from a market... Rather, a central counterparty redistributes counterparty risks, replacing a firm's exposure to bilateral credit risks (of variable quality) with the standard credit risk on the central counterparty" [17, p. 126].

Grody [18] and Cornford [19] also expressed doubts in their work about the ability of centralized clearing to prevent crises related to the circulation of OTC derivatives. Both researchers were inclined to believe that in the case of problems with the liquidity of the derivatives market, the central counterparty does not address the issue of increasing its level. The authors argue in favour of a government-led bailout fund which could be applied as a guarantee fund in the event of a market crisis.

However, the formation of a state fund for crisis assistance involves additional government expenditures, which are formed by taxpayers' contributions. Therefore, an ethical question of fairness arises: is it appropriate to withdraw taxpayers' money to cover the losses of financial institutions and other traders who have taken on excessive risk not covered by equity? In addition, it is worth estimating the optimal amount of such an aid fund, as transactions are concluded with a large leverage, so the nominal value of the derivative (at which it is traded) does not reflect the actual amount of liabilities arising from it.

Jan Job de Vries Robbe and Paul Ali draw attention to the riskiness of derivatives in their work mentioning that "derivatives as risk insurance instruments, at the same time act as a source of new risks when conducting operations in the world financial markets. The main danger of derivatives is that transactions with them, allowing the use of relatively small amounts of liquid funds, bring both large profits and losses (leverage)" [1]. At the same time, the authors do not distinguish between exchange and over-the-counter derivatives, because even in an organized market, the possibility of incorrect assessment of the commitments under these instruments is not excluded. In particular, losses on futures transactions also confirm the riskiness of exchange-traded derivatives (Table 1): Barings Bank (1995), Sumitomo Corporation (1996), Société Générale (2008) and others.

François Laurens [20], analysing the work by Edwards [8] "Off-exchange derivatives markets and financial fragility", summarized a certain sequence of development of the systemic crisis that could be caused by OTC derivatives: (1) an initial shock due to the failure of a large end-user; (2) the failure of a large derivatives dealer; (3) counterparty spill over effects; (4) market linkages spreading the "price break" (5) other dealers developing large credit problems which could, if these dealers are banks, create a loss of confidence, causing bank runs and bank failures; (6) deterioration in confidence, markets become less liquid, causing price breaks and forced liquidations of securities by investors around the world (liquidity crisis).

It is worth noting that this sequence of events of the financial crisis may be due to stock derivatives, especially when the latter fall sharply in price. In this case, all large traders will try to get rid of derivatives that fall in price, not just until they occur, but as soon as possible, because the market revaluation of the instrument in the direction of decline brings losses on 
a daily basis. The rise in offers to sell a derivative, falling in price, accelerates the decline in price, and, panicked, traders are trying to get out of positions in other similar derivatives. The market was blocked for some time by the liquidity crisis, because those instruments that were liquid are no longer needed. Traders who do not have time to close positions in derivatives that have fallen in price, calculate losses, and some lose solvency and declare default.

The process of unfolding the liquidity crisis in the derivatives market (including over-thecounter) cannot prevent the presence of a central counterparty, nor increase the requirements for disclosure of information about large market participants and their open positions. Undoubtedly, these "flexible" instruments for regulating over-the-counter derivatives markets are aimed at conscious traders who have been exposed to previously unknown variables to adequately assess the risk of the contract and its counterparty. But whether traders' market strategy will change in pursuit of high profits (which carry high risks) when the asymmetry of information in the derivatives market decreases remains an open question.

Derivatives, regardless of the market in which they are represented: exchange or overthe-counter, are characterized by certain threats that arise from their nature. First, derivatives are usually traded with a large leverage, which sometimes approaches $100 \%$. This means that participants, who do not always have enough capital to cover potential losses, enter the market.

Second, the complexity of valuation and the accounting and reflection of derivatives in the financial statements allow (sometimes unknowingly) overestimating profits or reducing losses. As a result, such manipulations lead to the accumulation of damage, which can be detected in a few years and lead to the bankruptcy of the trader, as in the case of Barings.

In addition, if the cases of the largest losses from derivative transactions are analysed, there can be seen the relationship between payments to senior management and the company's profit from trading in derivatives. The direct dependence of wages on the company's profits stimulates management to look for the most profitable (and risky) areas for investment. Sometimes the self-confidence of managers leads to the fact that they expose the company they manage to great risks in order to make a profit from derivative transactions.

Another unobvious problem that open positions in derivatives can cause is the complication of the financial situation, the root causes of which are not related to derivatives. In this case, derivative counterparties, seeing the deterioration of the company's financial condition, will require early fulfilment of obligations (closing positions) on derivatives, which will further reduce the level of liquidity and may lead to default.

\section{Conclusions}

Thus, the risks of derivatives are still incomparable with the instruments of regulators aimed at minimizing them. The threat of a systemic crisis, which can be catalysed by any unreliable derivatives, remains. In addition, the derivatives market continues to grow and be filled with new instruments, including bitcoin futures and options on bitcoin futures, despite the crisis surrounding the spread of the coronavirus pandemic. As of the beginning of 2020, the volume of issued exchange derivatives (at face value) amounted to 558.5 trillion US dollars, and considering OTC derivatives reached a value of 1 quadrillion US dollars, which is much higher than the world's GDP [21].

Therefore, to ensure stability of the global financial system, it is necessary to develop instruments to regulate the derivatives market, aimed at protecting large companies (not only banking institutions) from misapplication, including internal one. Such measures are partially implemented by setting disclosure requirements, but capital adequacy requirements will also be appropriate (such requirements are already in place for commercial banks), as well as limiting the share of investments in speculative derivatives that are not intended to hedge risk [22-87]. Further research should be aimed at substantiating the size of the allowable share of 
derivatives in the investment portfolio of large companies, as well as the mechanism of formation of internal reserves to ensure open positions in derivative financial instruments.

\section{References}

1. Z. de Vriz Robbe, P. Ali Securitization and Law (Alpina Business Books, Moscow 2008)

2. O. Novak, T. Osadcha, O. Petruk, Baltic Journal of Economic Studies, 5(3), 135-144 (2019)

3. L. Jacques, Dangerous games with derivatives: A half-century history of failures from Citibank to Barings (Alpina Publisher, Moscow, 2012)

4. List of trading losses. URL: http:// en.wikipedia.org/wiki/ List_of_trading_losses

5. Dzh. Sinki, Financial management in a commercial bank and in the financial services industry (Alpina Business Books, Moscow, 2007)

6. Ludger Hentschel and Cliffor W. Smith, Risk and Regulation in Derivative Markets. URL:http://ludgerhentschel.com/PDFs/RAR.pdf?fbclid=IwAR3tBXAVGMbFx1e5oi MC3TujwbI0Gi9_6XJQ9GRQhbL91tWWdK3g1Dt_YmE_(1994)

7. M.S. Scholes, Global financial markets, derivative securities, and systemic risks. Journal of Risk and Uncertainty, 12(2), 271-286 (1996)

8. F. R. Edwards, Journal of Financial Services Research, 9(3), 259-290 (1995)

9. Warren E. Buffett, Berkshire Hathaway INC. 2002 ANNUAL REPORT. URL: https://www.berkshirehathaway.com/2002ar/2002ar.pdf (2003)

10. Tamar Frankel, How Should the Financial Markets Be Regulated? URL: http://www.bu.edu/lawlibrary/facultypublications/PDFs/Frankel/Wall_St_lawyer.pdf (2008)

11. F. Wolak, How Should Financial Markets Be Regulated? URL: https://web.stanford.edu/group/fwolak/cgibin/sites/default/files/COMMENTARY_Stanford\%20University.pdf (2015)

12. The Basel Committee's response to the financial crisis: report to the G20. Report. Bank for International Settlements. URL: http://www.bis.org/publ/bcbs179.pdf. (2010)

13. US regulation for derivatives lawyers-overview. URL: https://www.lexisnexis.com/uk/lexispsl/financialservices/document/391289/5PVDVJS1-F185-X46N-00000-00/US-regulation-for-derivativeslawyers\%E2\%80\%94overview (2021)

14. EU regulation for derivatives lawyers-overview. URL: https://www.lexisnexis.com/uk/lexispsl/financialservices/document/391289/5PVDVJS1-F185-X405-00000-00/EU-regulation-for-derivativeslawyers\%E2\%80\%94overview (2021)

15. MIFID II. URL: https://www.esma.europa.eu/policy-rules/mifid-ii-and-mifir(2018)

16. A. Alder, A global perspective on derivatives regulation. URL: https://www.regulationtomorrow.com/eu/clearing-and-settlement/a-global-perspectiveon-derivatives-regulation/ (2021)

17. B. Hills, D. Rule, S. Parkinson, Central counterparty clearing houses and financial stability. Financial Stability Review. Bank of England. URL: http://www.jscc.co.jp/en/ccp12/materials/docs/11.pdf. (1999)

18. A. Grody, of Risk Management in Financial Institutions, 4(2), 112-116 (2011)

19. A.Cornford, Journal of Economic Issues, 30(2), 493-509 (1996) 
20. François Laurens, Regulation of financial derivatives markets: a review of the link between regulation and market liquidity. URL: https://www.researchgate.net/publication/272304266_Regulation_of_Financial_Deriva tives_Markets_A_Review_of_the_Link_between_Regulation_and_Market_Liquidity (2013)

21. Jeff Desjardins, All of the World's Money and Markets in One Visualization. URL: https://www.visualcapitalist.com/all-of-the-worlds-money-and-markets-in-onevisualization2020/?fbclid=IwAR2xHN1ExHUPkyPYjAzchpdo8RFe01GrJuI7Z0a3kJ10C2G1ff7A LE-6rNo (2020)

22. O. Melnychenko, Journal of Risk and Financial Management, 13(9), 191 (2020)

23. O. Melnychenko, Energies, 14(1), 210 (2021)

24. I. Shkodina, O. Melnychenko, M. Babenko, Financial and Credit Activity: Problems of Theory and Practice, 2(33), 513-521 (2020)

25. U. Vatamanyuk-Zelinska, O. Melnychenko, Problems and Perspectives in Management, 18(3), 11-27 (2020)

26. O. Melnychenko, Virtual Economics, 2(3), 30-40 (2019)

27. O. Burlaka, A. Kuzior, O. Hanych, S. Kravchenko, O. Melnychenko, Journal of Legal, Ethical and Regulatory Issues, 22(Special Issue 2), 1-5 (2019)

28. R. Kostyrko, T. Kosova, L. Kostyrko, L. Zaitseva, O. Melnychenko, Energies, 14, 5080 (2021)

29. S. Cyfert, A. Chwiłkowska-Kubala, W. Szumowski, R. Miśkiewicz, PLoS ONE, 16(4), e0249724 (2021)

30. B. Czyżewski, A. Matuszczak, R. Miskiewicz, Technological and Economic Development of Economy, 25(1), 82-102 (2019)

31. H. Dzwigol, M. Dzwigol-Barosz, R. Miskiewicz, A. Kwilinski, Entrepreneurship and Sustainability Issues, 7(4), 2630-2644 (2020)

32. H. Dzwigol, M. Dzwigol-Barosz, Z. Zhyvko, R. Miskiewicz, H. Pushak, Journal of Security and Sustainability Issues, 8(3), 307-317 (2019)

33. E. Gross-Golacka, M. Kusterka-Jefmanska, R. Miskiewicz, B. Jefmanski, A. Rzepka, T. Kupczyk, European Research Studies Journal, XXIV(2B), 410-429 (2021)

34. R. Miskiewicz, Polityka Energetyczna, 21(2), 49-62 (2018)

35. R. Miskiewicz, Virtual Economics, 2(2), 37-47 (2019)

36. R. Miskiewicz, Marketing and Management of Innovations, 3, 371-381 (2020)

37. R. Miskiewicz, Energies, 13(22), 6106 (2020)

38. R. Miśkiewicz, Journal of Risk and Financial Management, 14(2), 59 (2021)

39. R. Miśkiewicz, R. Wolniak, Sustainability, 12(14), 5776 (2020)

40. K. Pająk, O. Kvilinskyi, O. Fasiecka, R. Miskiewicz, Economics and Environment, 2(61), 122-138 (2017)

41. A. Rzepka, R. Borowiecki, R. Miskiewicz, Z. Olesinski, European Research Studies Journal, XXIV(2), 1149-1162 (2021)

42. P.W. Saługa, K. Szczepańska-Woszczyna, R. Miśkiewicz, M. Chłąd, Energies, 13(18), 4833 (2020)

43. H. Dzwigol, M. Dźwigoł-Barosz, A. Kwilinski, International Journal of Entrepreneurship, 24(1), 1-5 (2020) 
44. Y. Kharazishvili, A. Kwilinski, O. Grishnova, H. Dzwigol, Sustainability, 12(21), 8953 (2020)

45. Y. Kharazishvili, A. Kwilinski, O. Sukhodolia, H. Dzwigol, D. Bobro, J. Kotowicz, Energies, 14(8), 2126 (2021)

46. Y. Kharazishvili, A. Kwilinski, H. Dzwigol, V. Liashenko, Virtual Economics, 4(2), 740 (2021)

47. A. Kwilinski, O. Vyshnevskyi, H. Dzwigol, Journal of Risk and Financial Management, 13(7), 142 (2020)

48. O. Lyulyov, T. Pimonenko, A. Kwilinski, H. Dzwigol, M. Dzwigol-Barosz, V. Pavlyk, P. Barosz, Energies, 14(2), 373 (2021)

49. O. Lyulyov, I. Vakulenko, T. Pimonenko, A. Kwilinski, H. Dzwigol, M. DzwigolBarosz, Energies, 14(12), 3497 (2021)

50. A. Kwilinski, H. Dzwigol, V. Dementyev, International Journal of Entrepreneurship, 24(1 Special Issue), 1-5 (2020)

51. O. Arefieva, O. Polous, S. Arefiev, V. Tytykalo, A. Kwilinski, IOP Conference Series: Earth and Environmental Science, 628, 012039 (2021)

52. V. Boiko, A. Kwilinski, M. Misiuk, L. Boiko, Economic Annals-XXI, 175(1-2), 68-72 (2019)

53. S. Bogachov, A. Kwilinski, B. Miethlich, V. Bartosova, A. Gurnak, Entrepreneurship and Sustainability Issues, 8(2), 487-499 (2020)

54. O. Chygryn, Y. Bilan, A. Kwilinski, Marketing and Management of Innovations, 3, 356368 (2020)

55. V.V. Dementyev, A. Kwilinski, Journal of Institutional Studies, 12(1), 100-116 (2020)

56. V. Koibichuk, N. Ostrovska, F. Kashiyeva, A. Kwilinski, Marketing and Management of Innovations, 1, 253-265 (2021)

57. V. Kondratenko, O. Okopnyk, L. Ziganto, A. Kwilinski, Marketing and Management of Innovations, 1, 87-94 (2020)

58. A. Kuzior, A. Kwilinski, V. Tkachenko, V. Entrepreneurship and Sustainability, 7(2), 1353-1376 (2019)

59. A. Kuzior, A. Kwilinski, I. Hroznyi, Energies, 14(9), 2572 (2021)

60. A. Kuzior, O. Lyulyov, T. Pimonenko, A. Kwilinski, D. Krawczyk, Sustainability, 13(15), 8145 (2021)

61. A. Kwilinski, Virtual Economics, 1(1), 7-25 (2018)

62. A. Kwilinski, Marketing and Management of Innovations, 4, 116-128 (2018)

63. A. Kwilinski, Academy of Accounting and Financial Studies Journal, 23(SI2), 1-6 (2019)

64. A. Kwilinski, V. Tkachenko, A. Kuzior, Journal of Security and Sustainability Issues, 9(2), 561-570 (2019)

65. A. Kwilinski, N. Dalevska, S. Kravchenko, I. Hroznyi, I. Kovalenko, Journal of Entrepreneurship Education, 22(SI1), 1-7 (2019)

66. A. Kwilinski, I. Ruzhytskyi, V. Patlachuk, O. Patlachuk, B. Kaminska, Journal of Legal, Ethical and Regulatory Issues, 22(SI2), 1-6 (2019)

67. A. Kwilinski, R. Volynets, I. Berdnik, M. Holovko, P. Berzin, P. Journal of Legal, Ethical and Regulatory Issues, 22(SI2), 1-6 (2019) 
68. A. Kwilinski, K. Pajak, O. Halachenko, S. Vasylchak, Y. Pushak, P. Kuzior, Marketing and Management of Innovations, 4, 172-181 (2019)

69. A. Kwilinski, A. Kuzior, Management Systems in Production Engineering, 28(2), 119123 (2020)

70. A. Kwilinski, Y. Zaloznova, N. Trushkina, N. Rynkevych, E3S Web of Conferences, 168, $00031(2020)$

71. A. Kwilinski, M. Dielini, O. Mazuryk, V. Filippov, V. Kitseliuk, Journal of Security and Sustainability Issues, 10(1), 345-358 (2020)

72. A. Kwilinski, D. Shteingauz, V. Maslov, Financial and Credit Activities: Problems of Theory and Practice, 3(34), 133-140 (2020)

73. A. Kwilinski, I. Slatvitskaya, T. Dugar, L. Khodakivska, B. Derevyanko, International Journal of Entrepreneurship, 24(1 Special Issue), 1-8 (2020)

74. A. Kwilinski, V. Litvin, E. Kamchatova, J. Polusmiak, D. Mironova, International Journal of Entrepreneurship, 25(1), 1-8 (2021)

75. Y. Kyrylov, V. Hranovska, V. Boiko, A. Kwilinski, L. Boiko, L. Journal of Risk and Financial Management, 13(12), 303 (2020)

76. V. Lakhno, V. Malyukov, T. Bochulia, Z. Hipters, A. Kwilinski, O. Tomashevska, International Journal of Civil Engineering and Technology, 9(8), 1802-1812 (2018)

77. O. Lyulyov, T. Pimonenko, A. Kwilinski, Y. Us, E3S Web of Conferences, 250, 03006 (2021)

78. K. Pająk, B. Kamińska, O. Kvilinskyi, O. Financial and Credit Activity: Problems of Theory and Practice, 2(21), 204-217 (2016)

79. T. Savchenko, N. Basiurkina, O. Rodina, A. Kwilinski, Management Theory and Studies for Rural Business and Infrastructure Development, 41(1), 43-61 (2019)

80. V. Tkachenko, A. Kwilinski, O. Korystin, N. Svyrydiuk, I. Tkachenko, Journal of Security and Sustainability, 8(3), 375-385 (2019)

81. V. Tkachenko, A. Kwilinski, M. Klymchuk, I. Tkachenko, Management Systems in Production Engineering, 27(2), 119-123 (2019)

82. V. Tkachenko, A. Kwilinski, I. Tkachenko, P. Puzyrova, Marketing and Management of Innovations, 2, 228-238 (2019)

83. V. Tkachenko, A. Kwilinski, B. Kaminska, I. Tkachenko, P. Puzyrova, Financial and Credit Activity: Problems of Theory and Practice, 3(30), 85-94 (2019)

84. V. Tkachenko, A. Kuzior, A. Kwilinski, Journal of Entrepreneurship Education, 22(6), 1-10 (2019)

85. L. Karpenko, M. Serbov, A. Kwilinski, V. Makedon, S. Drobyazko, Academy of Strategic Management Journal, 17(5), 1-7 (2018)

86. J. Polcyn, Sustainability, 13(15), 6846 (2021)

87. R. Abazov, Herald of Journalism, 58(4), 34-43 (2021) 